\title{
Dipeptidyl Peptidase IV as a Novel Prognostic Marker and Important Therapeutic Target in Melanoma
}

Iwona Piatkowska-Chmiel ( $\sim$ iwona.piatkowska-chmiel@umlub.pl)

Medical University of Lublin: Uniwersytet Medyczny w Lublinie https://orcid.org/0000-0003-1829-6981

Monika Gawronska-Grzywacz

Medical University of Lublin: Uniwersytet Medyczny w Lublinie

Magdalena Iwan

Medical University of Lublin: Uniwersytet Medyczny w Lublinie

Dorota Natorska-Chomicka

Medical University of Lublin: Uniwersytet Medyczny w Lublinie

Mariola Herbet

Medical University of Lublin: Uniwersytet Medyczny w Lublinie

Agnieszka Korga-Plewko

Medical University of Lublin: Uniwersytet Medyczny w Lublinie

Jaroslaw Dudka

Medical University of Lublin: Uniwersytet Medyczny w Lublinie

\section{Research}

Keywords: dipeptidyl peptidase IV (DPP IV), prognostic molecular marker, targeted therapy, gliptins, melanoma

Posted Date: July 26th, 2021

DOI: https://doi.org/10.21203/rs.3.rs-688076/v1

License: (c) (1) This work is licensed under a Creative Commons Attribution 4.0 International License. Read Full License 


\section{Abstract}

\section{Background}

There is a lot of evidence which suggests that DPP IV level may correlate with a type of tumor cells, metastatic potential and prognosis for the patient. Bearing in mind that the melanomas are characterized by high heterogeneity and identification of specific phenotypes of cells allows for early and more effective therapy, the aim of our study was to check whether there is a correlation between the DPPIV and the metastatic potential of melanoma cell lines. Additionally, the aim of our research was to evaluate the anti-tumor potential of linagliptin and saxagliptin in melanoma cell lines as well as determining correlation between cytotoxicity of the drugs and DPP IV level.

Methods

The inhibitory effect of tested drugs on the cancer cell growth was assessed using MTT (3-(4,5dimethylthiazol-2-yl)-2,5-diphenyltetrazolium bromide) while cell cycle analysis and apoptosis were performed using the NucleoCounter ${ }^{\circledR} \mathrm{NC}-3000^{\mathrm{TM}}$ system (ChemoMetec, Denmark), following the instructions provided by the manufacturer. DPPIV release by cancer cells was measured by DPP4/CD26 ELISA assay kit for biological samples (Cloud-Clone Corp.,Wuhan,China).

Results

Our results showed that DPPIV overexpression promoted cell proliferation of melanoma cells. Our data showed that especially short term treatment with linagliptin is associated with not only decreased expression of DPPIV and inhibition of cell proliferation but also induction of cell cycle disruption and apoptosis in melanoma.

\section{Conclusions}

The routine identification of this glycoprotein in melanoma would be fundamental to assessing not only the risk of metastasis/disease progression but also selection of therapy and evaluation of its effectiveness.

\section{Background}

Cancer is one of the most common causes of mortality in the world [1]. Late-stage presentation of symptoms, untargeted diagnostic procedures leads to late diagnosis and treatment and thus poor prognosis for the patient. The most common types of cancer diagnosed in men are related to prostate, lung, colon and urinary bladder cancer (CRC). While in women, the three most common cancers are breast cancer (accounting for $30 \%$ of all cancer diagnoses), lung cancer, and colorectal cancer [2]. Over the past four decades, we observed a dynamic increase in the incidence of liver, kidney and skin cancer [3]. 
Melanoma is a skin cancer which belongs to the group of most aggressive human cancers having high ability of metastasis to other organs such as lungs, liver, brain, or lymph nodes [4]. It is one of the cancers that is still escalating in incidence [5]. More than more than $50 \%$ of cases of this cancer are diagnosed in advanced stages, which in turn leads to poor prognosis and elevated mortality [7]. The hallmarks of these tumors include a high biological heterogeneity of cells, highly infiltrative behavior and resistance to standard treatment [6]. Previous research indicates that melanoma cells present in the primary tumor undergo intense morphologic, genotypic and phenotypic changes which alters their signaling pathways and results in rapid development of cell resistance per applied therapy $[9,10]$.

The identification of specific cancer cells population by specific proteins or genes may be of high importance in the diagnosis of tumors with high cellular heterogeneity such as melanoma [11-15]. Additionally, the use of selected predictive markers characterized by specific sensitivity or resistance to certain forms of treatment could have practical application in both selection and evaluation of effective therapy. Despite significant progress in research on melanoma heterogeneity, the identification of individual sub-populations of cells is still extremely difficult. These diagnostic limitations are influenced not only by the high genetic diversity of cells, but also acquired heterogeneity, resulting from cell reaction to changes in the environment of growing tumor [16].

Dipeptidyl peptidase IV (DPPIV), also known as CD26 is a multifunctional glycoprotein present on the surface on numerous different cell types such as epithelia and endothelia of the systemic vasculature, lung, pancreas, spleen, kidney, small intestine, heart, hepatocytes and immune system cells [17-19]. Part of the studies shows the participation of DPPIV in the development of neoplastic diseases. Mechanisms that regulate DPPIV gene transcription and enzymatic activity in cancer cells are not fully understood so far. DPPIV expression may be dependent on various factors, including the studied cells type and phenotype, tumor location as well as grade of malignancy also from presence in surrounding of cancer tissues environmental factors [20-25]. DPP-IV can be strongly expressed in some cancer cells, while being absent or present at low levels in others [21, 26-29]. In some forms of cancer, increased cell invasiveness may be correlated with decreased CD26/DPP4 expression [30-35] while in other type of aggressive malignancies, such as ovarian cancer [36], renal cell carcinoma [37], chronic lymphocytic leukemia [38] or thyroid cancer [39] over-expression of DPPIV is observed. The available research shows that DPPIV expression level may play important role in pathogenesis of melanoma [21]. It is speculated that DPPIV expression level significantly affects the regulation of expression of bcl-2 family proteins and hence melanoma cells resistance to apoptotic death [40-43]. As it turns out one of the key factors contributing to changes in DPPIV expression and increased susceptibility of cells to oncogenic transformation is variable level of oxygen [44]. Previous research proved that, in response to hypoxia, HIF$1 \mathrm{a}$ is activated which strongly induces DPPIV expression. This process may be correlated with chemoresistance, metastasis and poor prognosis for patients with ovarian cancer [44, 45]. Also, studies on other types of human cells confirmed the significant influence of hypoxia on the level of DPP IV expression [46-48]. Other research also shows that melanocytes are more prone to oncogenic transformation when grown in a low oxygen microenvironment [49]. The available research shows that hypoxia contributes to the metabolic changes inside cancer cells and genomic changes that make it 
possible for the cells to adapt to very low oxygen concentrations and limited access to nutrients, thus remaining viable. Also, hypoxia can affect HIF1a or/and transcription factor (MITF) level in melanoma cells which determines differentiated and invasive this cancer cells [50-53]. So, the ratio of specific cell phenotypes and imbalance in both oxygen supply and consumption in a melanoma tumor may have fundamental meaning to DPPIV expression and hence disease progression as well as effectiveness of the therapy.

Given that the DPP-IV may play an important role in the pathogenesis of various human cancers, the aim of this study was to examine the level of DPPIV release by selected cancer cell lines characterized by high invasiveness and resistance to available therapies. Bearing in mind that the melanomas are characterized by high cellular heterogeneity and that early reliable identification of specific phenotypes of cells allows more efficient therapy, three different melanoma cell lines characterized by differential expression of DPPIV: SK-MEL-28, A-375 and G-361 were selected for the next stage of our research. Considering the fact that the tumors consists of cells with different metabolic phenotype and different sensitivity to periodic hypoxic states which may result in developing resistance to chemo- and radiotherapies, the aim of our research was to assess impact of hypoxia on the viability and DPPIV release by melanoma cells. In this study, we tested the hypothesis that linagliptin and saxagliptin, drugs belonging to DPPIV inhibitors by down regulation of DPPIV, may contribute to the growth control in melanoma cells by the inhibition of cell proliferation, cell cycle arrest and induction of apoptosis.

\section{Materials And Methods}

\subsection{Reagents}

Reagents were purchased from the following sources: linagliptin, saxagliptin (Selleckchem, Munich, Germany), thiazolyl blue tetrazolium bromide (MTT; Sigma-Aldrich, Steinheim, Germany), dimethyl sulfoxide (DMSO; POCH S.A. Avantor Performance Materials, Inc., Gliwice, Poland), phosphate-buffered saline (PBS; Mediatech, Inc. Corning Subsidiary, Manassas, VA, USA). The Eagle's Minimum Essential Medium (EMEM, ATCC, Manassas, VA, USA ), Dulbecco's Modified Eagle's Medium (DMEM, PAN-Biotech $\mathrm{GmbH}$, Aidenbach, Germany) or RPMI-1640 (PAN-Biotech GmbH, Aidenbach, Germany), foetal bovine serum (FBS) the antibiotics (penicillin, streptomycin, amphotericin B) were purchased from PAN-Biotech $\mathrm{GmbH}$ (Aidenbach, Germany). Trypsin solution (0.25\% trypsin/2.21 mM EDTA) was obtained from Mediatech, Inc. Corning Subsidiary (Manassas, VA, USA).

\subsection{Cell culture}

The cancer cell lines: PC-3 (catalog no. CRL-1435 $5^{\mathrm{m}}$ ), DU-145 (catalog no. HTB-81 ${ }^{\mathrm{Tm}}$ ), SK-MEL-28 (catalog no. HTB-72 ${ }^{\text {TM }}$ ), A-375 (catalog no. CRL-1619 ${ }^{\mathrm{Tm}}$ ), G-361 (catalog no. CRL-1424 ${ }^{\mathrm{m}}$ ), Hep G2 (catalog no. HB$8065^{\mathrm{TW}}$ ) and 769-P (catalog no.CRL-1933 ${ }^{\mathrm{TW}}$ ) were purchased from American Type Culture Collection (ATCC; Manassas, VA, USA) and cultured in EMEM, DMEM or RPMI-1640 medium with 10\% FBS and antibiotics: $100 \mathrm{U} / \mathrm{ml}$ penicillin, $100 \mu \mathrm{g} / \mathrm{ml}$ streptomycin and $2.5 \mu \mathrm{g} / \mathrm{ml}$ amphotericin B. The cell lines were routinely 
screened for mycoplasma and maintained in a humidified atmosphere with $5 \% \mathrm{CO}_{2}$ at $37^{\circ} \mathrm{C}$ in a cell incubator. Cells were grown in $75 \mathrm{~cm}^{2}$ tissue culture flasks (EasYFlasks ${ }^{\text {TM }}$ Nunclon $^{\text {TM }} \Delta$; Nalge Nunc International, Penfield, NY, USA). Before the experiment, cells were trypsinized $(0.25 \%$ trypsin $/ 2.21 \mathrm{mM}$ EDTA) and seeded in 96-well or 6-well plates (SPL Life Sciences, Pocheon, Korea) at a density of $1 \times 10^{5}$ cells $/ \mathrm{ml}$. The prepared plates were incubated for $24 \mathrm{~h}$ in order to achieve cell adhesion. After this time, drugs were added to the cells in the right concentrations and incubated for 24 hours. Control cells were incubated only with the appropriate medium to the line.

\subsection{Identification of DPPIV of cancer cell lines}

After treatment under various conditions cancer cells with or without DPPIV inhibitors for $24 \mathrm{~h}$, the culture medium was harvested and cells were washed with phosphate-buffered saline(PBS) and subsequently removed and were lysed by sonication with extract buffer (Lysis Buffer1; Cloud-Clone Corp.,Wuhan,China) and each lysate was then centrifuged at $9000 \times \mathrm{g}$ for $20 \mathrm{~min}$ at $4^{\circ} \mathrm{C}$. The cell culture supernatants were collected, and the DPPIV release by cancer cells was measured by DPP4/CD26 ELISA assay kit for biological samples (Cloud-Clone Corp.,Wuhan,China). The assays were performed in duplicates according to the manufacturer's instructions. The measurement was performed spectrophotometrically using a microplate reader at $450 \mathrm{~nm}$ wavelength. The protein concentrations were determined with the Bradford method using bovine serum albumin as a standard [76]. The DPPIV values were normalized by the amount of protein (Bradford method) and then leveled in proportion to the control.

\subsection{Selection of cancer cell lines}

To the next stage was selected melanoma cell lines on the basis of the differential expression of DPPIV with emphasis on high level of DPPIV in SK-Mel-28 cell line as compared to other cancer line. The melanoma cancer cell lines selected SK-MEL-28, A-375, G-361 represent cells with high and medium expression of DPPIV and diversified metastatic potential.

\subsection{Cell sensitivity of drugs and changing conditions/MTT assay}

The MTT assay was performed to investigate the cell proliferation and viability. It was made in accordance with DB-ALM Protocol no. 17 (European Centre for the Validation of Alternative Methods, Database Service on Alternative Methods to Animal Experimentation). The drugs (linagliptin, saxagliptin) were dissolved in DMSO to prepare a primary stock solutions (concentration of $1250 \mu \mathrm{M}$ ) and subsequently diluted to the final concentration with in appropriate medium for the line EMEM or DMEM medium. The solutions were prepared ex tempore. The final concentration of DMSO did not exceed $0.5 \%$ v/v and did not affect cell viability. Log phase SK-MEL-28, A-375, G-361 cells were seeded in 96-well plates were treated for $24 \mathrm{~h}$ with linagliptin or saxagliptin (concentration range of 20-1250 $\mu \mathrm{M}$ ) under normoxia ( $21 \% \mathrm{O} 2$ and $5 \% \mathrm{CO} 2)$ or hypoxia conditions. For hypoxia exposure, cells were incubated and treated in an in a sterilized anoxic-hypoxic chamber (Modular Incubator Chamber MIC-101, BillupsRothenberg). Cells had access to limited oxygen ( $1 \% 02,5 \%$ CO2, N2 to $94 \%)$ which is referred to as 
hypoxia. Subsequently, $10 \mu \mathrm{l}$ of 3-(4,5-dimethylthiazol-2-yl)-2,5-diphenyltetrazolium bromide (MTT) solution ( $5 \mathrm{mg} / \mathrm{ml}$ in PBS) were added to the each well of a microplate and incubated for an additional 3 $\mathrm{h}$ at $37^{\circ} \mathrm{C}$ each of the conditions. In the next step, free serum culture medium containing MTT was discarded from each well, and the formazan crystals were dissolved by addition $100 \mu$ DMSO. The absorbance was measured at $550 \mathrm{~nm}$ using a microplate reader ELx808IU (BioTek Instruments Inc., Winooski, VT, USA). The experiment was performed twice in triplicate. In the MTT assay, the extent of formazan crystal formation correlates with the number of viable cells.

\subsection{Cell cycle analysis}

Two-step cell cycle analysis was performed using the NucleoCounter ${ }^{\circledR}$ NC-3000 ${ }^{\text {TM }}$ system (Chemometec, Allerød, Denmark), following the instructions provided by the manufacturer. For cell cycle analysis, the SKMEL-28, A-375 and G-361 cells were seeded at a density of $1 \times 10^{5}$ cells $/ \mathrm{ml}$ in 35-mm 6-well plates, treated with IC50 concentrations of linagliptin and saxagliptin indicated above for $24 \mathrm{~h}$. After treatment, cells were washed with PBS and suspended in $250 \mu$ S Solution 10 (lysis buffer) supplemented with $10 \mu \mathrm{l}$ DAPI, and were incubated for $5 \mathrm{~min}$ at $37^{\circ} \mathrm{C}$, next was added $100 \mu$ Solution 11 (stabilization buffer). The suspension of cells was loaded into the chambers of the NC-Slide A $8^{\mathrm{TM}}$ in the volume of $10 \mu \mathrm{l}$, and subjected to cell-cycle analysis. The results in the form of a histograms represents the percentage division of cells in the different cell cycle phases (sub-G1/G1, S and G2/M).

\subsection{Cell apoptosis analysis}

Cell apoptosis analysis was conducted using the Annexin V assay for the NucleoCounter ${ }^{\circledR} \mathrm{NC}-3000^{\text {TM }}$ system, according to the manufacturer's instructions. The SK-MEL-28, A-375 and G-361 cells were seeded in 6-well plates and incubated $24 \mathrm{~h}$ with IC50 concentrations of linagliptin and saxsagliptin (78 and 468 $\mu \mathrm{M}$ for SK-Mel-28; 157.59 and 262.43 for A-375, 188.67 and 265.07 for G-361 respectively). After incubation, the cells were harvested by centrifugation at $400 \mathrm{~g}$ for $5 \mathrm{~min}$. Supernatant was carefully removed and the cell pellet was gently re-suspended in $100 \mu$ I Annexin V binding buffer, supplemented with $2 \mu \mathrm{l}$ Annexin V-CF488A and $2 \mu \mathrm{l}$ Hoechst 33342, and was incubated for $15 \mathrm{~min}$ at $37^{\circ} \mathrm{C}$. Subsequently, stained cells were centrifuged at $400 \mathrm{~g}$ for $5 \mathrm{~min}$ and re-suspended in $100 \mu \mathrm{l}$ Annexin V binding buffer with $10 \mu \mathrm{l}$ propidium iodide $(\mathrm{PI})$ solution. The suspension of stained cells was loaded into the chambers of the NC-Slide $A 2^{\text {TM }}$ in the volume of $30 \mu \mathrm{l}$, and subjected to cell-apoptosis analysis. The quantification of early apoptotic cells was based on Annexin V binding and PI exclusion. The obtained histograms were used to demarcate the percentages of PI negative cells with low vitality, PI negative cells with high vitality (healthy cells), and PI positive cells (dead cells).

\subsection{Statistical Analysis}

The results are expressed as mean \pm SD. The data represents the mean of 2 independent experiments, each consisting of 3 replicates. Data was analysed using the Student's $t$ test or one-way analysis of variance (ANOVA) wherever required using the program Graph Pad Prism software, version 8.0. I $\mathrm{I}_{50}$ 
values for the tested drugs were derived from the concentration-response curves. A $p$-value of $<0.05$ was considered to indicate a statistically significant result.

\section{Results}

\subsection{Identification of DPPIV in cancer cell lines}

DPPIV was identified in seven cancer cell lines: PC-3, DU-145, SK-Mel-28, A-375, G-361, 769-P, HepG2, representing four distinct tumor types (Fig. 1). The selected cancer cell lines represent different cells characterized by high, medium and low level of DPPIV. The results of the analysis showed that the DPPIV level was the highest in SK-MEL-28 cells and the lowest in human prostate carcinoma cell lines (PC-3 and DU-145). To the next stage of research, on the basis of the differential expression of DPPIV, the melanoma cell lines were selected with emphasis on high level of DPPIV in SK-Mel-28 as compared to other cancer lines. Selected melanoma cell lines (SK-Mel-28, A-375, G-361) represent cells with high and medium expression of DPPIV.

\subsection{Effect of hypoxia on viability of melanoma cells and level of DPPIV release}

As Fig. 2A shows, tested melanoma cell lines were sensitive to hypoxia. The G-361 line turned out to be most sensitive to hypoxia in the contrary to the least sensitive SK-Mel-28 cells. After 24 hours the cell viability was decreased by $60 \%(p<0.001 ; t=14.171 ; F=1.351)$ and $15 \%(p>0.05)$ respectively when compared to viability of normoxic cells. Given the high viability of SK-Mel-28 cells oxygen deprived, it can be concluded that these cells may be characterized by the glycolytic phenotype. There was not significant statistically difference in the viability of SK-Mel-28 cells under normoxic and hypoxic conditions $(p>0.05$; $t=2.24 ; F=3.08$ ).

Among the other examined melanoma lines, A-375 line was slightly less sensitive to the hypoxia than G361 line. The viability of this cell line was decreased by $32 \%$ under hypoxic conditions compared to cells grown under normoxic conditions $(p<0.01 ; t=6.640 ; \mathrm{F}=1,678)$.

In Fig. 2B, it can be seen that DPPIV level depends on not only culture conditions but also type of cell line. Under hypoxia conditions DPPIV level is down-regulated especially in SK-Mel-28 melanoma cell line. The hypoxia leads to significant decrease in DPPIV release by cancer cells (almost half; $p<0.001 ; t=39.202$; $F=8.733$ ) compared to the level of this parameter under normoxic conditions. In the case of A-375 cells and G-361 line, the significant differences in DPPIV levels released by these cell lines under hypoxic and normoxic conditions weren't observed ( $p>0.05$, the results aren't statistically significant).

Melanoma cells (SK-Mel-28, A-375 and G-361 lines) were cultured under normoxic or hypoxic (1\% O2 was referred as hypoxia) conditions for $24 \mathrm{hrs}$ and then measured: (A) The viability of cells by the MTT assay. Cell viability in hypoxia was calculated vs. the same line of cells in normoxia which was set to $100 \%$ viability; (B) DPPIV level was measured in the cell lysates by DPP4/CD26 ELISA assay kit. DPPIV level in 
hypoxia was compared with level of this parameter in the same line of cells in normoxia. The data represent the mean of 2 independent experiments, each consisting of 3 replicates. The bars represent the means \pm SD. $\left({ }^{\star} p<0.05,{ }^{* \star} p<0.01,{ }^{* \star *} p<0.001\right.$ compared to normoxic cells).

\subsection{Evaluate of sensitivity of melanoma cell lines to linagliptin and saxagliptin under hypoxia and normoxia}

In general, linagliptin was significantly more active in evaluated melanoma cell lines in hypoxic environment than saxagliptin (Fig. 3A-F). It was most noticeable for SK-Mel-28 line. Linagliptin use in concentrations above $100 \mu \mathrm{M}$ led to a very dynamic decrease in the viability of this cancer cells line under hypoxic conditions compared to the viability of normoxic cells (Fig. 3A). Linagliptin at a concentrations $\geq$ $250 \mu \mathrm{M}$ showed 95\% cytotoxicity against the SK-Mel-28 line $(p<0.001 ; t=9,313 ; \mathrm{F}=25.584)$. Saxagliptin showed significantly the lowest efficiency in relation to this cancer line under hypoxia compared to normoxia (Fig. 3D). It only in a concentration above $750 \mu \mathrm{M}$ significantly decreased the viability of SKMel-28 cells compared to the viability of normoxic cells. Furthermore hypoxia significantly increased resistance of SK-Mel-28 line to low concentrations of both linagliptin and saxagliptin (Fig. 3A, 3D).

Exposure of A-375 melanoma line to drugs in hypoxic conditions effectively reduced their viability (Fig. 3B, 3E). Linagliptin and saxagliptin significantly inhibited A-375 cell survival in a wide concentration range $(20-1250 \mu \mathrm{M}, p<0.01, p<0.001)$ under hypoxic conditions compared to cells treated under normoxic conditions. Nearly identical results were observed for G-361 line. The aforementioned cells were sensitive to the cytotoxic effect of drugs already at the lowest concentrations compared to the viability of normoxic cells (Fig. 3C and 3F).

All the melanoma cells tested - SK-Mel-28, A-375, G-361, were incubated with different concentrations (20$1250 \mu \mathrm{M}$ ) of linagliptin (A, B and C) or saxagliptin (D, E and F) for 24 hours under hypoxic (red lines) or normoxic conditions (blue lines). Sensitivity of melanoma cell lines were evaluated by measuring cell viability by the MTT assay ( $\mathrm{n}=3$ replicate experiments for each cell line with each drug). ${ }^{\star} p<0.05,{ }^{\star \star} p<$ $0.01, * * \star p<0.001$ compared to normoxic cells.

\subsection{Effect of linagliptin and saxagliptin on DPPIV release by melanoma cell lines}

$24 \mathrm{hrs}$ after administration of test drugs at concentrations corresponding to their $\mathrm{IC}_{50}$ values estimated in appropriate lines, DPPIV level released by the melanoma cells was determined. SK-Mel-28 cells treated with linagliptin in a concentration of $78.26 \mu \mathrm{M}$ or saxagliptin in a concentration of $468.72 \mu \mathrm{M}$ remained sensitive to both drugs and showed the decrease of DPPIV levels (Fig. 4A, $p<0.001, t=5.993, F=9.175 ; p$ $<0.01, t=4.586, F=13.735$, respectively). Linagliptin and saxagliptin reduced DPPIV level by $43 \%$ and $36 \%$ in the SK-Mel-28 cell line, respectively. Also, incubation of A-375 and G-361 cell lines with linagliptin (in concentration $157.59 \mu \mathrm{M}$ or $188.67 \mu \mathrm{M}$ respectively) or saxagliptin (262.43 or $265.07 \mu \mathrm{M}$, respectively) led to a significant decrease of DPPIV level released by cells compared to DPPIV levels in untreated cells (Fig. $4 \mathrm{~B} p<0.01, \mathrm{t}=3.658, \mathrm{~F}=3.268$; Fig. $4 \mathrm{C} p<0.05, \mathrm{t}=2.694, \mathrm{~F}=1.657$ ). In all the tested melanoma 
lines, it was observed that DPPIV level release in linagliptin-exposed cells was lower than in saxagliptintreated cells (by $10-15 \%)$.

DPP IV release by cancer cells was measured by DPP4/CD26 ELISA assay kit after treatment; SK-Mel-28 cells (A), A-375 cells (B) and G-361 cells (C) were incubated for 24 hours with linagliptin or saxagliptin. Linagliptin at a concentration of $78.26,157.59$ or $188.67 \mu \mathrm{M}$ was selected for study as these values represented the $\mathrm{IC}_{50}$ for the Sk-Mel-28, A-375 and G-361 melanoma cell lines, respectively. We were guided by the same rationale in selecting saxagliptin concentrations $(468.72,262.43$ or 265.07 respectively). Data represents the mean of two independent experiments, each consisting of three replicates. ${ }^{*} p<0.01$, $\star \star \star x p 0.001$ compared to untreated melanoma cells.

\subsection{Effect of linagliptin or saxagliptin on the cell cycle of melanoma cells}

In SK-Mel-28 cells, both linagliptin and saxagliptin slightly increased the percentage of these cells in the G1 phase. The number of cells in this stage of the cell cycle increased by $9-17 \%$, vs. the untreated cells (Fig. 5A). Linagliptin at a concentration of $157.59 \mu \mathrm{M}$ or $188.67 \mu \mathrm{M}$, respectively, resulted in sub-G1 cell cycle arrest in A-375 and G-361 cells (Fig. 5B-C). However, the changes were the most visible in case of G361 cells where the increase by $38 \%$ was observed in above-mentioned cell cycle phase. In turn, saxagliptin used at concentration corresponding to its $\mathrm{IC}_{50}$ (i.e. $262.43 \mu \mathrm{M}$ or $265.07 \mu \mathrm{M}$ ) moderately affect the cell cycle of melanoma A-375 or G-361 cell lines (Fig. 5B-C). In addition, it was observed a decrease by $2-5$ fold of cells in the $\mathrm{G} 2$ phase in all melanoma lines after the application of appropriate $\mathrm{IC}_{50}$ concentrations of linagliptin or saxagliptin (Fig. 5A-C).

\subsection{Effect of linagliptin and saxagliptin on the cell apoptosis of melanoma cells}

In melanoma cells stained with Annexin V-CF488A and propidium iodide (PI), there was observed an apoptogenic potential of linagliptin and saxagliptin (Fig. 6A-C). Both linagliptin (78.26 $\mu \mathrm{M})$ and saxagliptin $(468.72 \mu \mathrm{M})$ induced early and late apoptotic mechanisms in SK-Mel-28 cells (Fig. 6A). As shown in Fig. 6B, in A-375 cell line, a treatment with saxagliptin in a concentration of $262.43 \mu \mathrm{M}$ led to a 3 -fold increase of cell number in the early phase of apoptosis, while after an incubation with linagliptin in a concentration of $157.59 \mu \mathrm{M}$ almost 2-fold increase was noted when compared to untreated cells. In addition, the population of late apoptotic cells was enhanced by $29 \%$ or $25 \%$ after treatment with linagliptin or saxagliptin, respectively. In turn, the number of necrotic cells in SK-Mel-28 and A-375 lines was slightly increased after 24-h incubation with drugs.

In the case of G-361 cell line, there was only a significant increase in the number of early apoptotic cells from $7-20 \%$ after application of saxagliptin in a concentration of $265.07 \mu \mathrm{M}$. In turn, linagliptin in a concentration of $188.67 \mu \mathrm{M}$ led to a significant increase in the percentage of late apoptotic cells (by $64 \%$ ) (Fig. 6C) while remaining without any significant effect on the early apoptotic cells' population. Neither 
linagliptin nor saxagliptin, significantly enhanced the number of necrotic cells in G-361 line. The number of these cells ranged from 3 to $5 \%$.

The melanoma cells were stained with Annexin V (Annexin V-CF488A) and propidium iodide (PI). Scatter plots demonstrate percentage of viable, apoptotic and necrotic SK-Mel-28 (A), A-375 (B), G-361(C) cells after a 24-h treatment with linagliptin or saxagliptin. The lower left square presents viable cells; right lower square shows early apoptotic cells; right upper square shows late apoptotic cells, and left upper square presents necrotic cells.

\section{Discussion}

Melanoma is one of the most complex and heterogeneous cancers $[9,10,54]$. Despite significant progress in research on melanoma heterogeneity, the identification of individual sub-populations of cells is still extremely difficult. These diagnostic limitations are influenced not only by the high genetic diversity of cells (in melanoma is the highest frequency of mutation from all cancers), but also acquired heterogeneity, resulting from cell reaction to changes in the environment of growing tumor. The literature data indicate that about $55 \%$ of solid tumors (including melanomas) are characterized by areas of hypoxia or anoxia in where the oxygen concentration doesn't excel $1.5 \%[51,55,56]$.

The available research shows that DPPIV glycoprotein can play an important role in development and progression of neoplastic diseases probably through the enzymatic and non-enzymatic mechanisms. An analysis of the available literature indicates differential CD26/DPP4 expression in different cancer types [26-38]. Our research confirmed differential expression of DPPIV in well-known cancer cell lines PC-3, DU145, SK-Mel-28, A-375, G-361, 769-P, HepG2 representing 4 distinct tumor types. Our research showed that the greatest changes in the released glycoprotein level were observed between three different melanoma cell lines SK-MEL-28, A-375 and G-361. The human melanoma cell lines used in our studies have been previously described as lines of high and low metastatic potential, respectively [60]. It was already determined that the sensitivity of tumor cells to changes in microenvironmental conditions like oxygen or nutrient deficiency can be diverse (from adaptation up to cells death) [57-60].

Research shows melanoma cells are capable of adapting quickly to changing microenvironmental conditions by leading to cellular metabolism changes (from oxidative phosphorylation to aerobic glycolysis for sufficient ATP production) $[51,56,58,59]$. Our research indicates diverse sensitivity of melanoma cells to oxygen deficiency both in terms of cell viability and DPPIV glycoprotein levels. The SKMel-28 line known for high metastatic potential, was distinguished from other melanoma lines by a high viability but also level of DPPIV under hypoxia conditions. It should be noted that there was no research prior to ours which would evaluate the level of DPPIV in this melanoma cell line under conditions of hypoxic growth that mimics the tumor microenvironment.

Based on the analysis of the available literature, it can be concluded that hypoxia changes the $\mathrm{pH}$ in the intracellular and extracellular space. This could trigger an adaptive response among melanoma cells and activate glycolysis which stimulates intense growth of cells despite the seemingly unfavorable 
environmental conditions [61, 62]. The glycolytic phenotype of melanoma cells appears to be closely associated with higher metastatic potential and resistance to anti-cancer therapy.

Widmer et al. [51] showed that under hypoxic conditions the invasiveness of proliferative melanoma cell may be increased from 2- to 4-fold. Feige et al. [52] reached similar conclusions that hypoxia, through HIF1a, alters the gene-expression in proliferative melanoma cells, making them more invasive in in vitro assays. Cheli et al.[53] showed that hypoxic conditions lead to a decrease in microphthalmia-associated transcription factor (MITF) expression which leads to increase in metastatic potential of melanoma cells in vivo. On the other hand, significantly lower cell viability of the A-375 and G-361, known for their low metastatic potential $[60,67]$, may suggest that hypoxia is not a factor which can trigger these cells adaptive switch to highly proliferative phenotype.

In our studies we noticed that, DPPIV level may depend not only on type of melanoma cell line but also on culture conditions. The change in the microenvironmental conditions for SK-Mel-28 cells determined the level of glycoprotein released by them. We didn't observe such dependencies for other tested melanoma lines. Regardless of the aforementioned observations, we were surprised with high level of glycoprotein released by examined melanoma cells. The analysis of limited number of available previous studies pointed to decrease or loss of CD26/DPPIV expression in the course of neoplastic transformation of melanocytes [21-23, 43]. In turn, the noticeable differences in the level of DPPIV released by SK-Mel-28 in the environmental conditions tested, may be due to activation of glycolysis by hypoxia which leads to extracellular acidosis of melanoma. This process could eventually result in lower DPPIV level compared to the level of this parameter under normoxic conditions (the optimal pH for DPPIV is 7.8) [61, 62].

Our studies found that DPPIV inhibitors, especially linagliptin, can inhibit melanoma cell proliferation in hypoxia conditions. Already the lowest concentrations of drugs dynamically reduced viability of the most sensitive to hypoxia cell lines: A-375 and G-361. Linagliptin at a concentration of $157.59 \mu \mathrm{M}$ or 188.67 $\mu \mathrm{M}$, respectively, significantly inhibited recruitment of the above-mentioned melanoma cells from sub-G1 phase to further stages of the cell cycle. Interestingly, the most hypoxic-resistant SK-Mel-28 line has undergone cytotoxic effects of linagliptin $\left(\mathrm{IC}_{50} 78.26 \mu \mathrm{M}\right)$ considered to be the most potent and selective dipeptidylpeptidase IV (DPPIV) inhibitors in this class of antidiabetic agents [71]. Linagliptin triggered early and late apoptosis of the above-mentioned melanoma cells. A 2-fold increase of early apoptotic cells and over a 10-fold enhancement of late apoptotic cells were noticed after treatment with this gliptin. Also, Li et al. [72] revealed, the cytotoxic action of linagliptin in colorectal cancer cell line. The cytotoxic effect of linagliptin was dependent on the dose and the time of exposure of cancer cells. Linagliptin significantly inhibited HCT116 cell proliferation by cell cycle arrest at G2/M and S phase and the induction of cell apoptosis. In our study, we observed the increased population of SK-Mel-28 cells in G1 phase after treatment with aforementioned gliptin. Yang et al.[73] confirmed the anti-cancer activity of sitagliptin in their research. Sitagliptin limited cell proliferation and invasiveness of endometrial cancer through regulation of HIF-1 $a$ and VEGFA signaling dependent on DPPIV expression. 
Our results showed that lowering the level of DPPIV in all melanoma cell lines correlated with apoptogenic potential of linagliptin and saxagliptin. Despite extensive research into the new molecules which can initiate and regulate apoptosis in melanomas, still there is no enough information on how to effectively limit their chemoresistance. The gliptins we tested, especially linagliptin, turned out to be strong inducers of apoptosis in melanoma cells which are known not only from apoptotic pathway evasion strategy, but also from the unchecked proliferation. Linagliptin and saxagliptin in melanoma cells, induced both early and late apoptotic mechanisms $[43,75]$. Moreover, the activation of apoptosis by DPPIV inhibitors led to a significant decrease in the number of viable melanoma cells. This may suggest that DPPIV is a promising therapeutic target for melanomas treatment.

In the future study, we want to provide information on the role of DPPIV inhibitors in modulation of melanoma cells resistance in available anti-cancer therapies. We want to check whether modulation of DPPIV expression translates to delay of melanoma cells resistance of anti-cancer therapy.

\section{Conclusions}

In our humble opinion, DPPIV should strongly be considered as a prognostic marker in screening tests of melanoma. The presence of high DPPIV level in SK-Mel-28 cell line under normoxia and hypoxia makes it possible to conclude that thanks to this glycoprotein it is possible to identify this particular cell line in a heterogeneous sample tumor, regardless of oxygen availability for this cells. Finally, routine identification of this glycoprotein in melanoma cells would be fundamental to assess not only the risk of metastasis/disease progression but also selection of therapy as well as evaluation of its effectiveness.

Our results also show that DPP IV may represent a potential novel therapeutic target for melanoma. Perhaps, in the future gliptins turn out to be important components of anti-cancer therapies to enhance their cytotoxic effect or they will constitute an alternative form of therapy when conventional treatment does not provide satisfactory results.

\section{Declarations}

\section{Ethics Approval and Consent to participate}

Not applicable.

\section{Consent for publication}

Not applicable.

\section{Availability of supporting data}

Not applicable.

\section{Competing interests}


The authors declare no conflict of interest.

Funding

The present study was supported by Funds for Statutory Activity of Medical University of Lublin, Poland (grant no. DS38/2020).

\section{Authors' Contributions}

Conceptualization, IPC; Methodology, IPC, MGG; Formal Analysis, DNC and MH; Data Curation, MH, Ml; Investigation, IPC, MI and DNC; Visualization, DNC, MI; Supervision, MH and AKP; Writing - Original Draft Preparation, IPC; Writing - Review \& Editing, MGG, AKP and JD. All authors read and approved the final version of manuscript.

\section{Acknowledgements}

Special thanks to Kamil Pawlowski for helping in statistical analysis and graphic processing of the results. We also thank Marcin Sysa for providing language help. All authors read and approved the final manuscript.

\section{References}

1. World Cancer Report: Cancer Research for Cancer Prevention Edited by Wild CP, Weiderpass E, Stewart BW.https: //publications.iarc.fr/586. 15.10.2020.

2. Siegel RL, Miller KD, Jemal A. Cancer statistics, 2019 https://doi.org/10.3322/caac.21551.01.09.2020.

3. Madan V, Lear JT, Szeimies RM. Non-melanoma skin cancer. Lancet 2010;375: 673-685.

4. Lerner AB, McGuire JS. Melanocyte-stimulating hormone and adrenocorticotrophic hormone. Their relation to pigmentation. $\mathrm{N}$ Engl.J Med 1964; 270:539-46.

5. Garbe C, Leiter U. Melanoma epidemiology and trends. Clin Dermatol. 2009;27:3-9.

6. Trojan SE, Piwowar M, Ostrowska B, Laidler P, Kocemba-Pilarczy KA. Analysis of Malignant Melanoma Cell Lines Exposed to Hypoxia Reveals the Importance of PFKFB4 Overexpression for Disease Progression. Anticancer Res.2018; 38:6745-6752.doi:10.21873/anticanres.13044

7. Slominski AT, Carlson JA. Melanoma resistance: a bright future for academicians and a challenge for patient advocates. Mayo Clin Proc. 2014;89:429-433.

8. Domingues B, Lopes J, Soares P, Populo H. Melanoma treatment in review ImmunoTargets Ther. 2018;7:35-49. 10.2147/ITT.S134842.

9. Ruiter D, Bogenrieder T, Elder D. et al. Melanoma interactions: structural and functional aspects. Lancet Oncol. 2002;3:35-43.

10. Li Y, Laterra J. Cancer stem cells: distinct entities or dynamically regulated phenotypes? Cancer Res. 2012; 72: 576-580. 
11. Magro CM, Crowson, AN, Mihm MC. Unusual variants of malignant melanoma. Mod. Pathol. 2006;19:41-70.

12. Freedman JA, Tyler DS, Nevins JR, Augustine CK. Use of gene expression and pathway signatures to characterize the complexity of human melanoma. Am. J Pathol. 2011; 178: 2513-2522.

13. Carreira S, Goodall J, Denat L, Rodriguez M, Nuciforo P, Hoek KS, Testori A, Larue L., GodingMitf CR. Regulation of Dia1 controls melanoma proliferation and invasiveness. Genes Dev. 2006;20: 34263439 .

14. Müller J, Krijgsman O, Tsoi J, Robert L, Hugo W, Song C, Kong X, Possik PA, Cornelissen-Steijger PDM, Foppen MHG, Kemper K, Goding CR, McDermott U, Blank C, Haanen J, Graeber TG, Ribas A, Lo RS, Peeper DS. Low MITF/AXL ratio predicts early resistance to multiple targeted drugs in melanoma Nat. Commun. 2014;5;:5712-5745. doi: 10.1038/ncomms6712.

15. Tirosh I, Izar B, Prakadan SM, Li MHW, Treacy D, Trombetta JJ, Rotem A, Rodman C, Lian C, Murphy G, Fallahi-Sichani M, Dutton-Regester K, Lin J, Kazer SW, Gaillard A, Kolb KE. Dissecting the multicellular exosystem of metastatic melanoma by single-cell RNA-seq. Science.2016;352: 189196. doi: 10.1126/science.aad0501.

16. Weinstein D, Leininger J, Hamby C, Safai B. Diagnostic and Prognostic Biomarkers in Melanoma. J Clin Aesthet Dermatol. 2014; 7:13-24.

17. Lambeir AM, Durinx C, Scharpé S, Meester I. Dipeptidyl-peptidase IV from bench to bedside: an update on structural properties, functions, and clinical aspects of the enzyme DPP IV. Crit Rev Clin Lab Sci. 2003; 40:209-294.

18. Aertgeerts K, Ye S, Tennant MG, Kraus ML, Rogers J, Sang BC, Skene RJ, Webb DR, Prasad GS.Crystal structure of human dipeptidyl peptidase IV in complex with a decapeptide reveals details on substrate specificity and tetrahedral intermediate formation. Protein Sci. 2004;13:412-421.

19. Durinx C, Lambeir AM, Bosmans E, Falmagne JB, Berghmans R, Haemers A, Scharpe S. Molecular characterization of dipeptidyl peptidase activity in serum: soluble CD26/dipeptidyl peptidase IV is responsible for the release of X-Pro dipeptides. Eur J Biochem. 2000; 267:5608-5613.

20. Beckenkamp A, Davies S, Willig JB, Buffon A. DPPIV/CD26: A tumor suppressor or a marker of malignancy? Tumour Biol. 2016;37:7059-7073.

21. Havre PA, Abe M, Urasaki Y, Ohnuma K, Morimoto C., Dang NH. The role of CD26/dipeptidyl peptidase IV in cancer. Front. Biosci. 2008;13:1634-1645.

22. Aertgeerts K, Ye S, Tennant MG,Kraus ML, Rogers J, Sang BC, Skene RJ, Webb DR, Prasad GS. Crystal structure of human dipeptidyl peptidase IV in complex with a decapeptide reveals details on substrate specificity and tetrahedral intermediate formation. Protein Sci. 2004;13;412-421.

23. Stulc T, Sedo A. Inhibition of multifunctional dipeptidyl peptidase-IV: Is there a risk of oncological and immunological adverse effects? Diab. Res. Clin. Pract 2010; 88:125-131.

24. Hyams DM, Cook RW, Buzaid AC. Identification of risk in cutaneous melanoma patients: Prognostic and predictive markers. J Surg Oncol. 2019;119: 175-186. doi: 10.1002/jso.25319. 
25. Zhong J, Gong Q, Goud A, Srinivasamaharaj S, Rajagopalan S. Recent Advances in DipeptidylPeptidase-4 Inhibition Therapy: Lessons from the Bench and Clinical Trials. J. Diabetes Res. 2015;2015 doi: 10.1155/2015/606031.

26. Javidroozi M, Zucker S, Chen WT. Plasma seprase and DPP4 levels as markers of disease and prognosis in cancer. Dis Markers. 2012;32:309-20.doi: 10.3233/DMA-2011-0889.

27. Cordero OJ, Salgado FJ, Nogueira M. On the origin of serum CD26 and its altered concentration in cancer patients. Cancer Immunol Immunother. 2009;58:1723-47. doi: 10.1007/s00262-009-0728-1.

28. Khin EE, Kikkawa F, Ino K, Kajiyama H, Suzuki T, Shibata K, Tamakoshi K, Nagasaka T, Mizutani S. Dipeptidyl peptidase IV expression in endometrial endometrioid adenocarcinoma and its inverse correlation with tumor grade. Am J Obstet Gynecol. 2003;188:670-6. doi: 10.1067/mob.2003.169.

29. Jie-Jen L, Tao-Yeuan W, Chien-Liang L, Ming-Nan C, Ming-Jen C, Yi-Chiung H, Ching-Hsiang L, ShihPing C. Dipeptidyl Peptidase IV as a prognostic marker and therapeutic target in papillary thyroid carcinoma. J Clin Endocrinol Metab. 2017;102:2930-2940.

30. Wesley UV, McGroarty M, Homoyouni A. Dipeptidyl peptidase inhibits malignant phenotype of prostate cancer cells by blocking basic fibroblast growth factor signaling pathway. Cancer Res. 2005;65:1325-34.

31. Arscott WT, LaBauve AE, May V, Wesley UV. Suppression of neuroblastoma growth by dipeptidyl peptidase IV: relevance of chemokine regulation and caspase activation. Oncogene. 2009;28:479-91.

32. Boccardi V, Marano L, Rossetti RRA, Rizzo MR, Martino N, Paolisso G. Serum CD26 levels in patients with gastric cancer: a novel potential diagnostic marker Boccardietal. BMCCancer.2015;15:703 DOI 10.1186/s12885-015-1757-0.

33. Dimitrova M, Ivanov I, Todorova R, Ste-fanova N, Moskova-Doumanova V, Topou-Yzova-Hristova T. et al. Comparison of the activity levels and localization of dipeptidyl peptidase IV in normal and tumor human lung cells. Tissue Cell. 2012; 44(2):74-9.

34. Cordero OJ, Imbernon M, Chiara LD, Martinez-Zorzano VS, Ayude D, de la Cadena MP, RodriguezBerrocal FJ. Potential of soluble CD26 as a serum marker for colorectal cancer detection. World J Clin Oncol 2011;2:245-61.

35. Wilson MJ, Ruhland AR, Quast BJ, Reddy PK, Ewnig SL, Sinha AA. Dipeptidylpeptidase IV activities are elevated in prostate cancers and adjacent benign hyperplastic glands. J Androl. 2000; 21:220226.

36. Moffit LR, Bilandzic M, Wilson AL, Chen Y, Gorrell MD, Oehler MK, Plebanski M., Stephens AN. Hypoxia Regulates DPP4 expression, proteolytic inactivation, and shedding from ovarian cancer cells. Int. J. Mol. Sci 2020; 21: 8110-24 doi:10.3390/ijms21218110.

37. Inamoto T, Yamochi T, Ohnuma K, Iwata S, Kina S, Inamoto S, Tachibana M, Katsuoka Y, Dang NH, Morimoto C. Anti-CD26 monoclonal antibody-mediated G1-S arrest of human renal clear cell carcinoma Caki-2 is associated with retinoblastoma substrate dephosphorylation, cyclin-dependent kinase 2 reduction, p27(kip1) enhancement, and disruption of binding to the extracellular matrix. Clin. Cancer Res. 2006;12: 3470-7. 
38. Cro L, Morabito F, Zucal N, Fabris S, Lionetti M, Cutrona G, Rossi F, Gentile M, Ferrario A, Ferrarini M, Molica S, Neri A, Baldini L. CD26 expression in mature B-cell neoplasia: its possible role as a new prognostic marker in B-CLL. Hematol Oncol. 2009;27:140-7.

39. Hirai K., Kotani T, Aratake Y, Ohtaki S, Kuma K. Dipeptidyl peptidase IV (DPP IV/CD26) staining predicts distant metastasis of 'benign' thyroid tumor. Pathol Inter .1999; 49:264-265.

40. Bush JA, Li G. The role of Bcl-2 family members in the progression of cutaneous melanoma. Clin Exper Metastasis. 2003; 20:531-539.

41. Ramsay JA, From L, Kahn HJ. Bcl-2 protein expression in melanocytic neoplasms of the skin. Mod. Pathol. 1995;8:150-154.

42. Albino AP, Sozzi G, Nanus DM, Jhanwar SC, Houghton AN. Malignant transformation of human melanocytes: induction of a complete melanoma phenotype and genotype. Oncogene. 1992; 7: 231521.

43. Wesley UV, Albino AP, Tiwari S, Houghton AN. A role for dipeptidyl peptidase IV in suppressing the malignant phenotype of melanocytic Cells. J Exp Med. 1999; 190:311-322.

44. Kim KS, Sengupta S, Berk M, Kwak YG, Escobar PF, Belinson J, Mok SC, Xu Y. Hypoxia enhances lysophosphatidic acid responsiveness in ovarian cancer cells and lysophosphatidic acid induces ovarian tumor metastasis in vivo. Cancer Res. 2006; 66:7983-7990. doi: 10.1158/0008-5472.CAN05-4381.

45. McEvoy LM, O'Toole SA, Spillane CD, Martin CM, Gallagher MF, Stordal B, Blackshields G, Sheils O, O'Leary JJ. Identifying novel hypoxia-associated markers of chemoresistance in ovarian cancer. BMC Cancer. 2015;25,547.

46. Röhrborn D, Eckel J, Sell H. Shedding of dipeptidyl peptidase 4 is mediated by metalloproteases and up-regulated by hypoxia in human adipocytes and smooth muscle cells. FEBS Lett. 2014;588:38703877. doi: 10.1016/j.febslet.2014.08.029.

47. Dang DT, Chun SY, Burkitt K, Abe M, Chen S, Havre P, Mabjeesh NJ, Heath El, Vogelzang NJ, CruzCorrea M. et al. Hypoxia-inducible factor-1 target genes as indicators of tumor vessel response to vascular endothelial growth factor inhibition. Cancer Res. 2008;68:1872-1880. doi: 10.1158/00085472.CAN-07-1589.

48. Chowdhury HH, Velebit J, Mekjavic IB, Eiken O, Kreft M, Zorec R. Systemic hypoxia increases the expression of DPP4 in preadipocytes of healthy human Participants. Exp Clin Endocrinol Diab. 2018; 126: 91-95.

49. Bedogni B, Welford SM, Cassarino DS, Nickoloff BJ, Giaccia AJ, Powell MB. The hypoxic microenvironment of the skin contributes to Akt mediated melanocyte transformation. Cancer Cell. 2005; 8,443-454.

50. Hoek KS, Eichhoff OM, Schlegel NC, Döbbeling U, Kobert N, Schaerer L, Hemmi S, Dummer.R. In vivo switching of human melanoma cells between proliferative and invasive states. Cancer Res. 2008;68:650-656. 
51. Widmer DS., Hoek KS, Cheng PF, Eichhoff OM, Biedermann T, Raaijmakers MIG, Hemmi S, Dummer R, Levesque MP. Hypoxia Contributes to Melanoma Heterogeneity by Triggering HIF1a-Dependent Phenotype Switching. J Invest Dermatol. 2013; 133:2436-2443.

52. Feige E, Yokoyama S, Levy C, Khaled M, Igras V, Lin RJ, Lee S, Widlund HR, Granter SR, Kung AL, Fisher DE. Hypoxia-induced transcriptionalrepression of the melanoma-associated oncogene MITF. Proc Natl Acad Sci. https://pubmed.ncbi.nlm.nih.gov/21949374/ 2011;25,E924-33.doi: 10.1073/pnas.1106351108. Epub 2011 Sep 26.

53. Cheli Y, Giuliano S, Fenouille N, Allegra M, Hofman V, Hofman P, Bahadoran Lacour JP, TartareDeckert S, Bertolotto C, Ballotti R. Hypoxia and MITF control metastatic behaviour in mouse and human melanoma cells. Oncogene. 2012;31:2461-2470.

54. Andor N, Graham TA, Jansen M, Xia LC, Aktipis CA, Petritsch C, Ji HP, Maley CC. Pan-cancer analysis of the extent and consequences of intratumor heterogeneity. Nat Med. 2016; 22:105-113.

55. Lawrence MS, Stojanov P, Polak P, Kryukov GV, Cibulskis K, Sivachenko A, Carter SL, Stewart C, Mermel $\mathrm{CH}$, Roberts SA. Mutational heterogeneity in cancer and the search for new cancerassociated genes. Nature. 2013; 499, 214-218.

56. Grzywa TM, Paskal W, Włodarski PK. Intratumor and Intertumor Heterogeneity in Melanoma. Transl Oncol. 2017;10: 956-975.doi: 10.1016/j.tranon.2017.09.007.

57. Strese S, Fryknäs M, Larsson R, Gullbo J. Effects of hypoxia on human cancer cell line chemosensitivity. Cancer 2013;13:331-342.

58. Farzana Ahmed F, Haass NK. Microenvironment-Driven Dynamic Heterogeneity and Phenotypic Plasticity as a Mechanism of melanoma therapy resistance. Front Oncol. 2018 https://doi.org/10.3389/fonc.2018.00173.

59. O'Connell MP, Marchbank K., Webster MR, Valiga AA, Kaur A, Vultur A, Li L, Herlyn M, Villanueva J. Liu Q. Hypoxia induces phenotypic plasticity and therapy resistance in melanoma via the tyrosine kinase receptors ROR1 and ROR2. Cancer Discov. 2013;3:1378-1393.

60. Kim HY, Lee H, Kim SH, Jin H, Bae J, Choi HK. Discovery of potential biomarkers in human melanoma cells with different metastatic potential by metabolic and lipidomic profiling. Sci Rep. 2017; 7:8864. doi: 10.1038/s41598-017-08433-9

61. Hosseini M, Kasraian Z, Rezvan HR. Energy metabolism in skin cancers: A therapeutic perspective. BBB. 2017; 1858: 712-722.

62. Yoshimoto T, Fischl M, Orlowski RC, Walter R. Post-proline cleaving enzyme and post-proline dipeptidyl aminopeptidase. Comparison of two peptidases with high specificity for proline residues. J Biol Chem. 1978; 253:3708-3716.

63. Pucciarelli D, Lengger N, Takáčová M, Csaderova L, Bartosova M, Breiteneder $H$, Pastorekova S, Hafner Ch. Hypoxia increases the heterogeneity of melanoma cell populations and affects the response to vemurafenib. Mol Med Rap. 2016;10:3281-3288. https://doi.org/10.3892/mmr.2016.4888 
64. Rohwer N, Cramer T. Hypoxia-mediated drug resistance: novel insights on the functional interaction of HIFs and cell death pathways. Drug Resist Updat. 2011; 14:191-201. doi:

10.1016/j.drup.2011.03.001.

65. Vergis R, Corbishley CM, Norman AR. Intrinsic markers of tumourhypoxia and angiogenesis in localised prostate cancer and outcome ofradical treatment: a retrospective analysis of two randomised radiotherapytrials and one surgical cohort study.Lancet Oncol. 2008; 9,342-5.

66. Kozara I., Marguea Ch, Rothengatterb S, Haana C, Kreisa S. Many ways to resistance: How melanoma cells evade targeted therapies. BBA 2019; 1871: 313-322.

67. Omholt K, Platz A, Kanter L, Ringborg U, Hansson J. NRAS and BRAF mutations arise early during melanoma pathogenesis and are preserved throughout tumor progression. Clin Cancer Res. 2003; 9:6483-6488.

68. Grau C, Khalil AA, Nordsmark M, Horsman MR, Overgaard J. The relationship between carbon monoxide breathing, tumour oxygenation and local tumour control in the $\mathrm{C} 3 \mathrm{H}$ mammary carcinoma in vivo. Br J Cancer. 1994; 69:50-57. doi: 10.1038/bjc.1994.8

69. Brizel DM, Dodge RK, Clough RW, Dewhirst MW. Oxygenation of head and neck cancer: changes during radiotherapy and impact on treatment outcome. Radiother Oncol. 1999; 53,113-117. doi: 10.1016/S0167-8140(99)00102-4.

70. Hockel M, Schlenger K, Aral B, Mitze M, Schaffer U, Vaupel P. Association between tumor hypoxia and malignant progression in advanced cancer of the uterine cervix. Cancer Res. 1996; 56:45094515.

71. Nabeno M, Akahoshi F, Kishida H, Miyaguchi I, Tanaka Y, Ishii S. et al. Comparative study of the binding modes of recently launched dipeptidyl peptidase IV inhibitors in the active site. Biochem Biophys Res Commun. 2013; 434:191-96. doi: 10.1016/j.bbrc.2013.03.010.

72. Li Y, Li Y, Li D, Li K., Quan Z, Wang Z, Zhenxiao Sun. Repositioning of Hypoglycemic Drug Linagliptin for Cancer Treatment. Front Pharmacol. 2020; 11:187. doi: 10.3389/fphar.2020.00187

73. Yang Y, Zhang X, Wu R, Huang Q, Jiang Y, Qin J, Yao F, Jin G, Zhang Y. DPPIV promotes endometrial carcinoma cell proliferation, invasion and tumorigenesis. Oncotarget. 2017; 8: 86798692.

74. Pang R, Law WL, Chu AC, Poon JT, Lam CS, Chow AK, Ng L, Cheung LW, Lan XR, Lan HY, Tan VP, Yau TC, Poon RT, Wong BC. A subpopulation of CD26+ cancer stem cells with metastatic capacity in human colorectal cancer. Cell Stem Cell. 2010;6:603-615.

75. Adewale FO, Basiru AO, Ayorinde OO, Israel OI, Oluwafemi OA. Regulacja apoptotycznej i nekroptotycznej śmierci komórek w raku skóry. J Cancer Biol Res. 2017; 5:1108-1117.

76. Bradford MM. A rapid and sensitive method for the quantitation of microgram quantities of protein utilizing the principle of protein-dye binding. Anal Biochem. 1976;72:248-254.

\section{Figures}




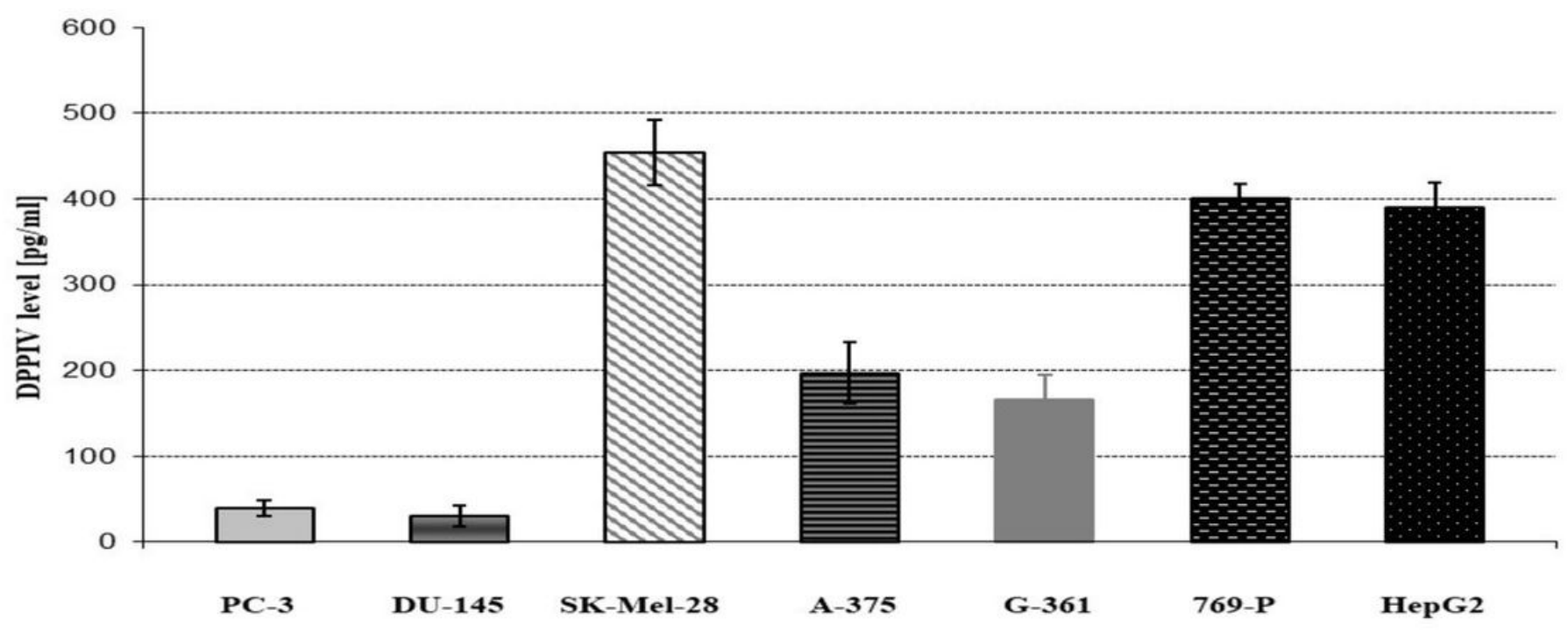

Figure 1

Level of DPPIV in selected human cancer cell lines. Level of DPPIV was measured in cancer cell lysates by DPP4/CD26 ELISA assay kit. The data represent the mean of 2 independent experiments, each consisting of 3 replicates. The bars represent the means \pm SD. 
$2 \mathrm{~A}$

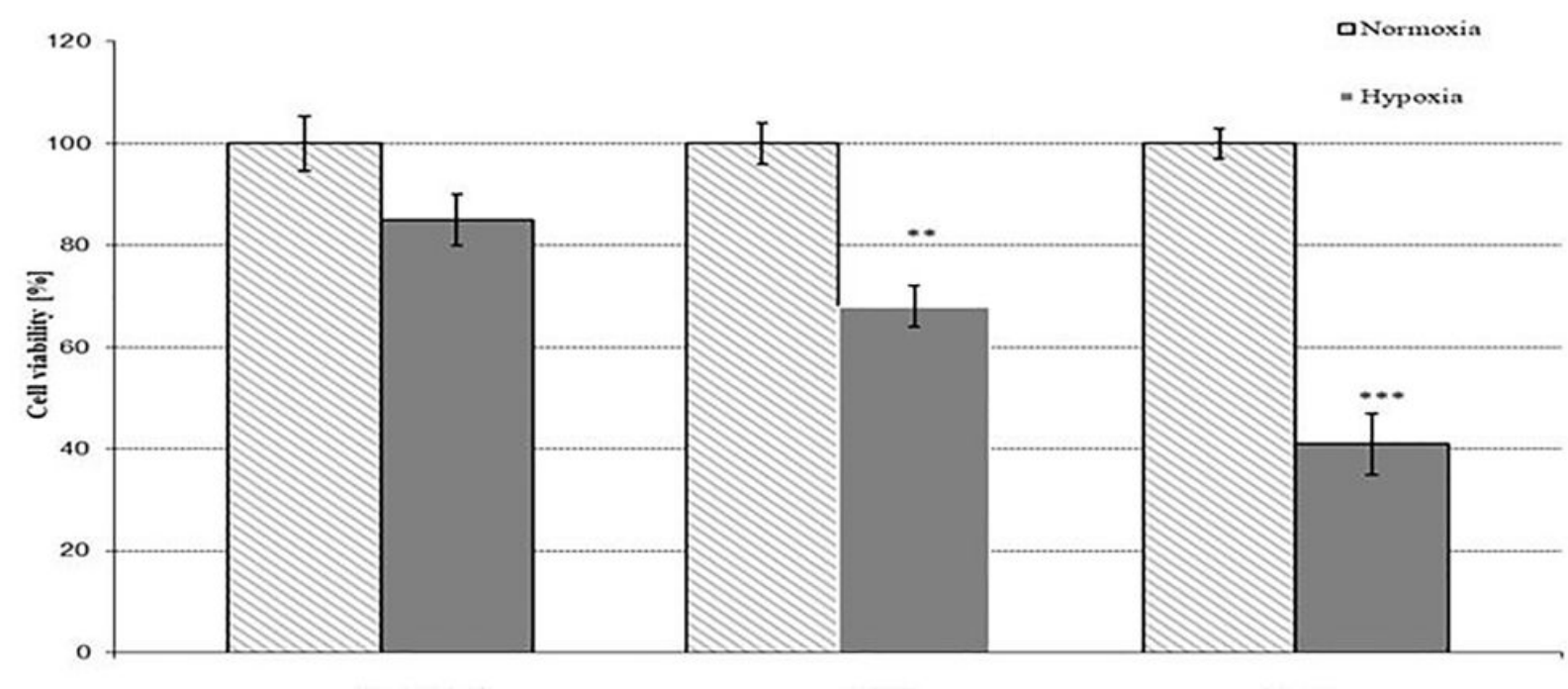

SK-Mel-28

A-375

G-361

2B

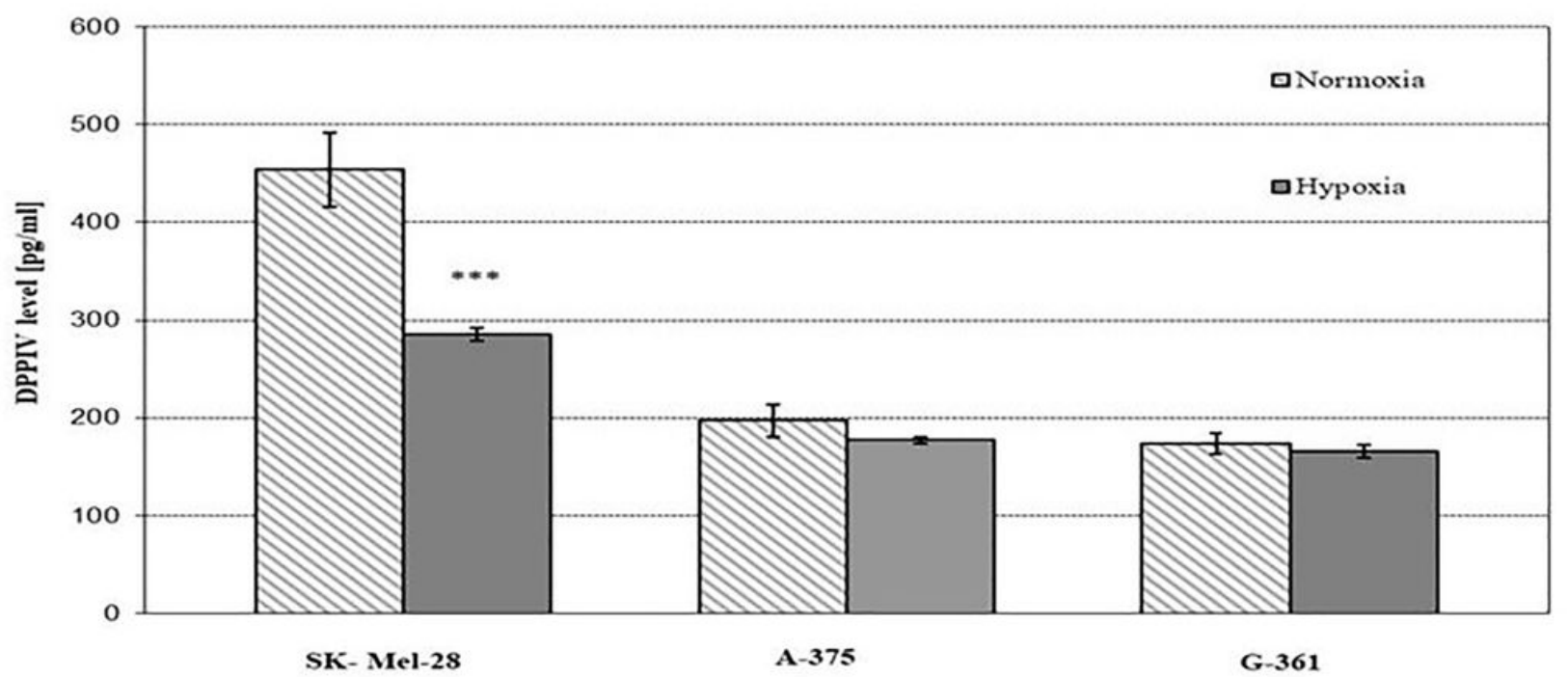

Figure 2

Effect of hypoxic conditions on viability of human melanoma cells and level of DPPIV release. 
$3 \mathrm{~A}$
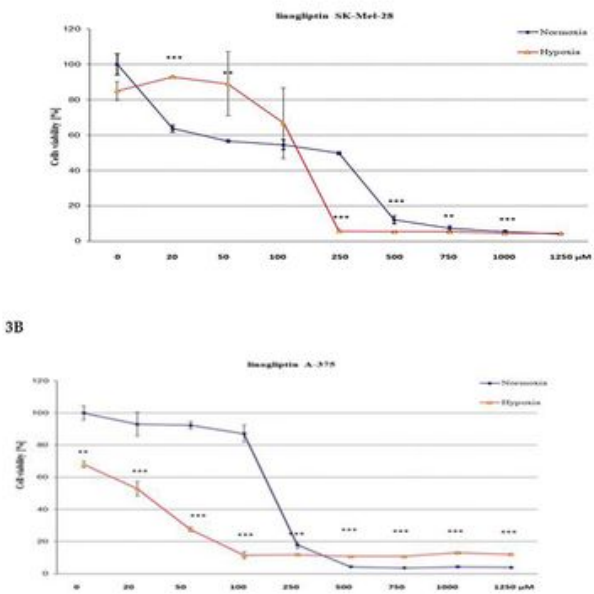

$3 \mathrm{C}$

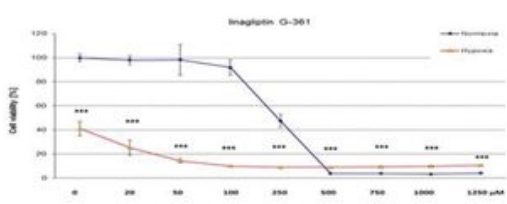

3D

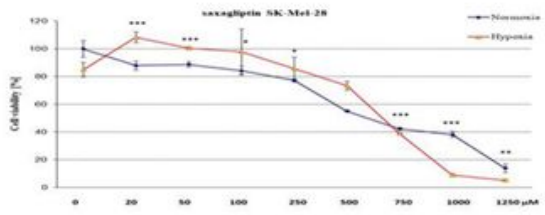

$3 \mathrm{E}$

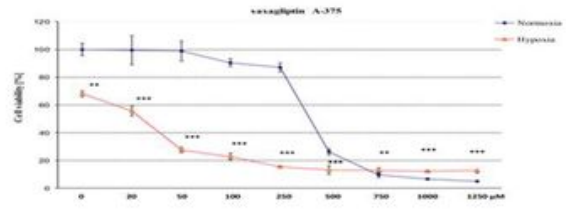

3 F

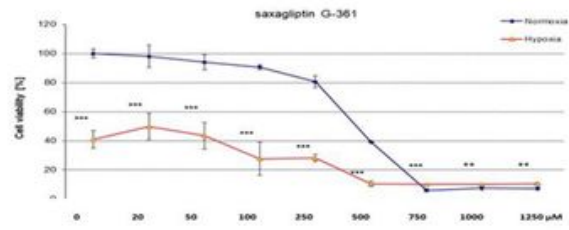

Figure 3

Effect of linagliptin or saxagliptin on viability of melanoma cell line in normoxia and hypoxia conditions. All the melanoma cells tested - SK-Mel-28, A-375, G-361, were incubated with different concentrations (20$1250 \mu \mathrm{M}$ ) of linagliptin (A, B and C) or saxagliptin (D, E and F) for 24 hours under hypoxic (red lines) or normoxic conditions (blue lines). Sensitivity of melanoma cell lines were evaluated by measuring cell 
viability by the MTT assay ( $n=3$ replicate experiments for each cell line with each drug). ${ }^{*} p<0.05$, ${ }^{*} \mathrm{p}<0.01, * \star * \mathrm{p}<0.001$ compared to normoxic cells.

4A

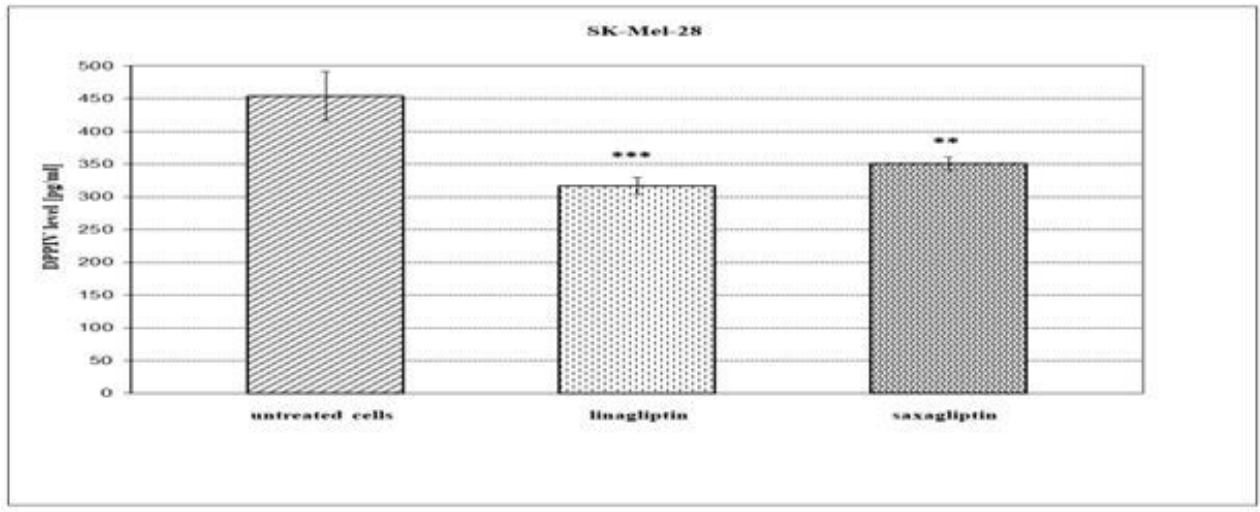

$4 \mathrm{~B}$

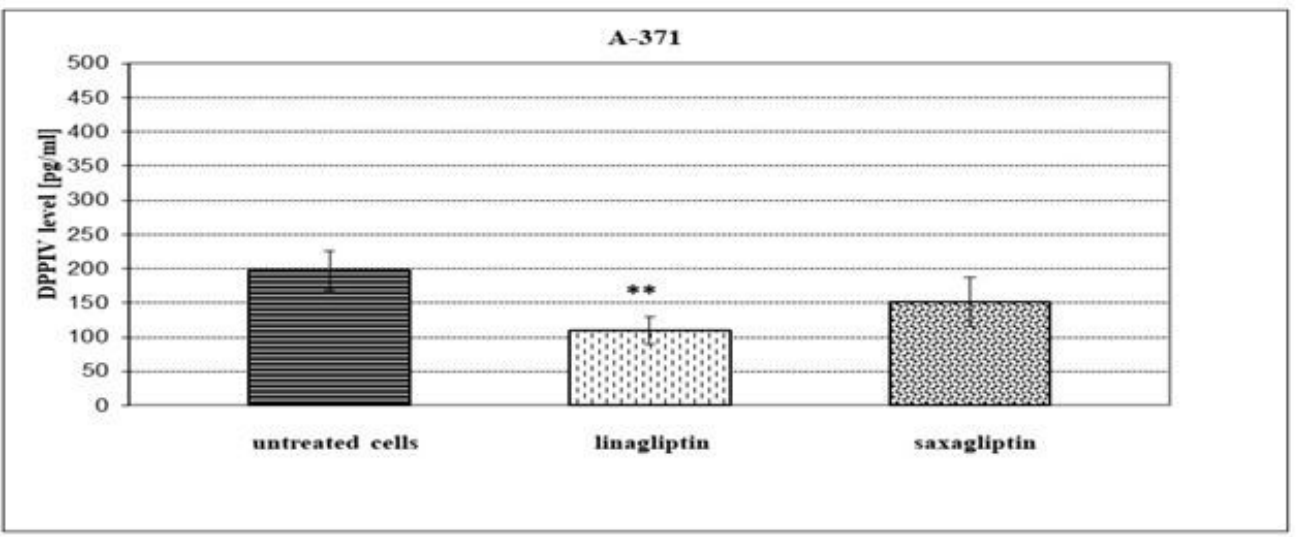

4C

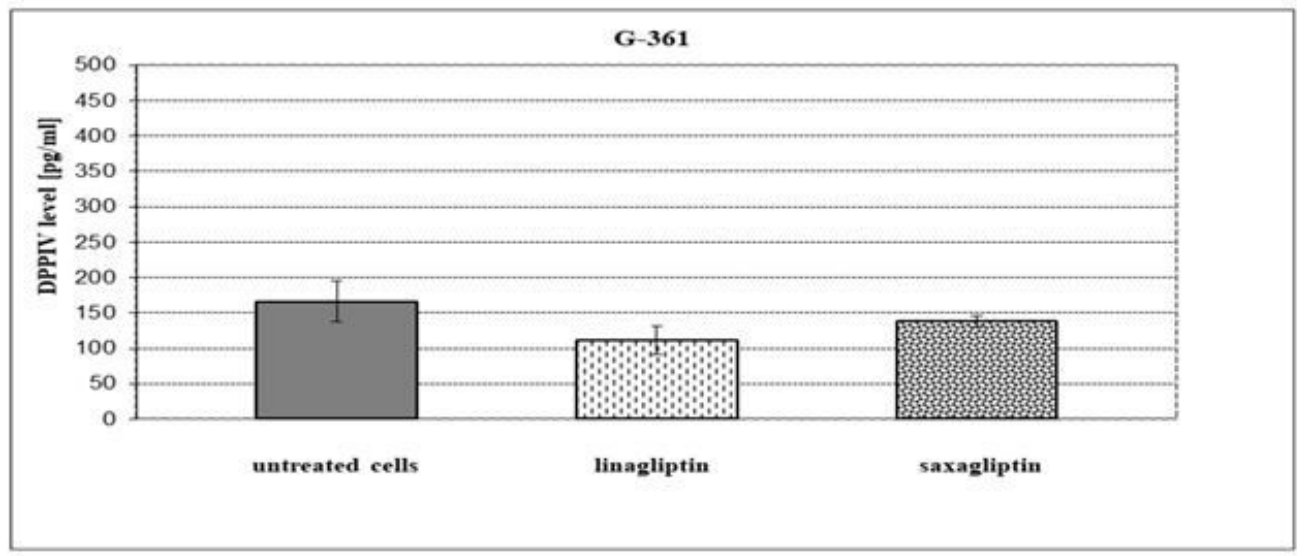

Figure 4

Effect of linagliptin and saxagliptin on DPP IV release by melanoma cells. 


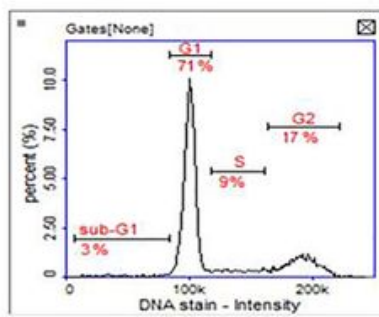

untreated cell.

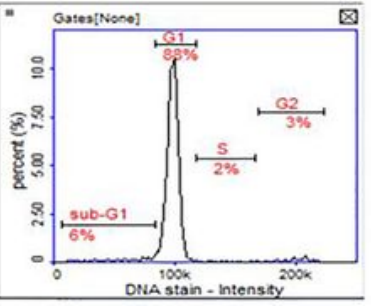

Hinagliptin

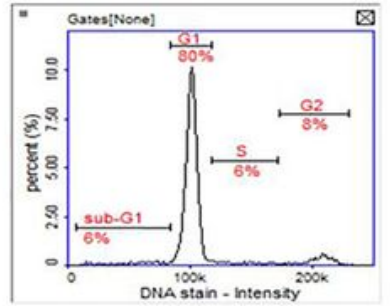

saxagliptin

B) A-375

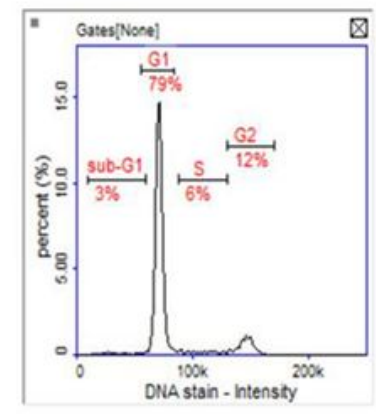

untreated cells

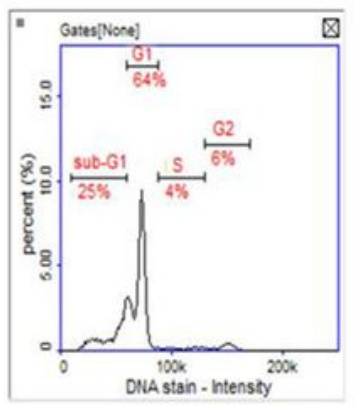

linagliptin

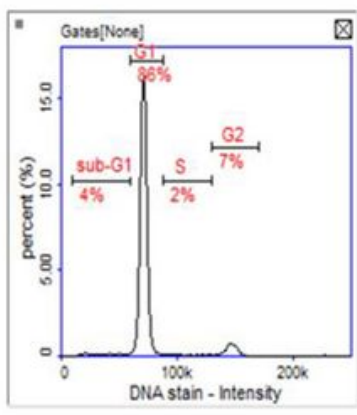

saxagliptin

C) G-36!
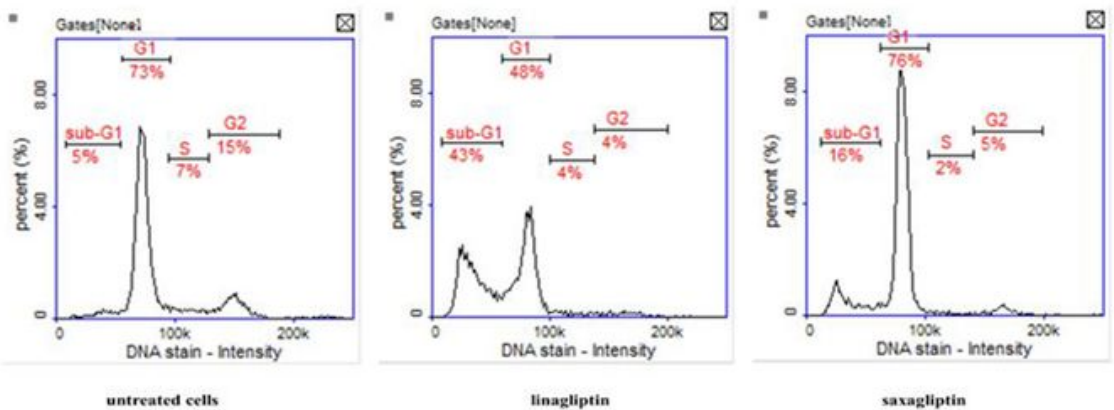

\section{Figure 5}

Cell cycle analysis of melanoma cell line SK-Mel-28 (A), A-375 cells (B) and G-361 cells (C) following a 24-h incubation with linagliptin or saxagliptin. The determination of the percentage division of SK-Mel-28 cells (A), A-375 cells (B) and G-361 cells (C) in cell cycle phases was investigated by an image analysis using the automated NC-3000 ${ }^{\mathrm{TM}}$ system based on DAPI (4',6-diamidino-2-phenylindole). The values indicate the percentage of cells in the indicated phases of the cell cycle (sub-G1/G1, S and G2/M). 


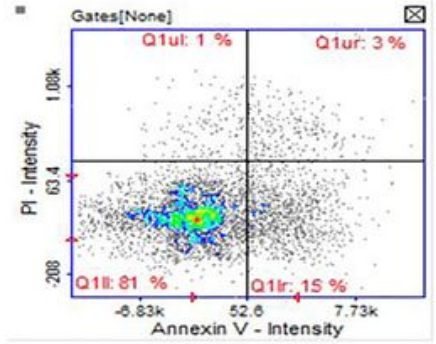

untreated eells

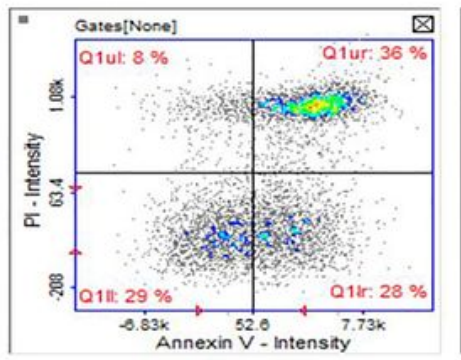

linagliptin

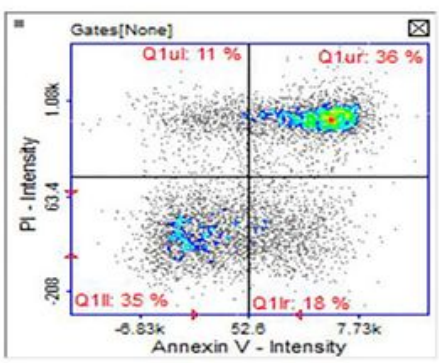

saxagliptin

B) ^-375

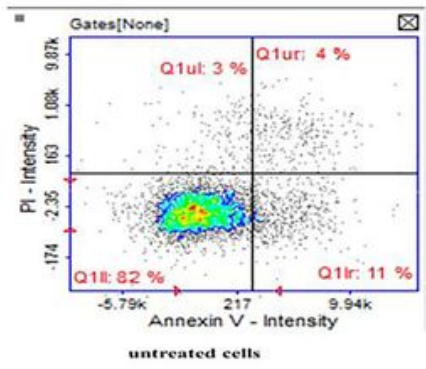

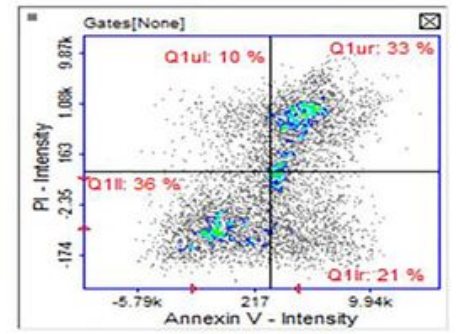

linagliptin

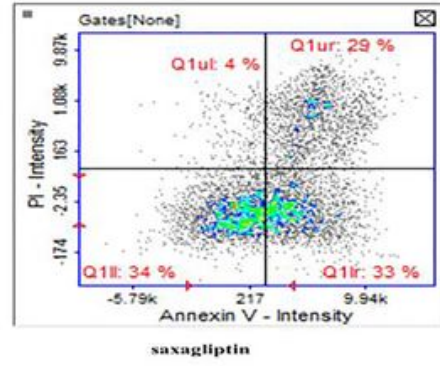

saxagliptin

C) G-361

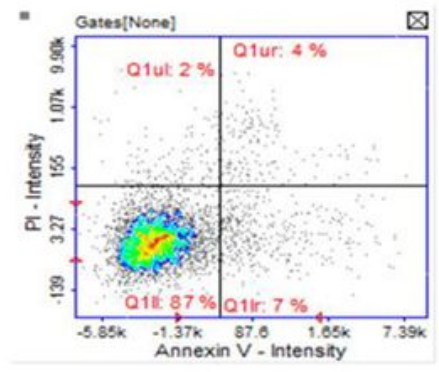

untreated cells

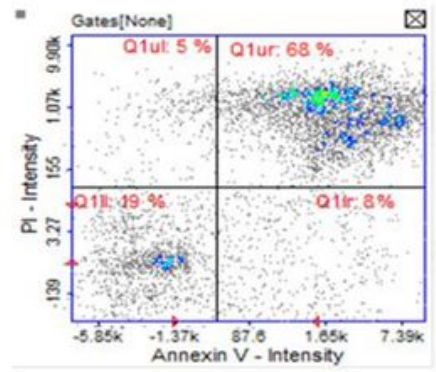

linagliptin

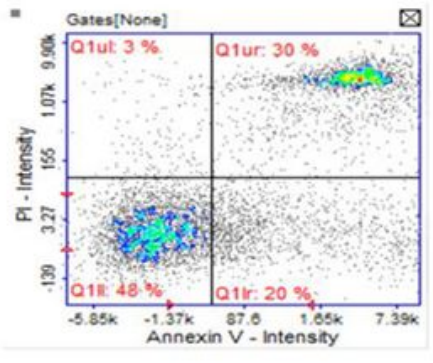

saxagliptin

\section{Figure 6}

Effect of linagliptin or saxagliptin on cell apoptosis of melanoma cells The melanoma cells were stained with Annexin V (Annexin V-CF488A) and propidium iodide (PI). Scatter plots demonstrate percentage of viable, apoptotic and necrotic SK-Mel-28 (A), A-375 (B), G-361(C) cells after a 24-h treatment with linagliptin or saxagliptin. The lower left square presents viable cells; right lower square shows early 
apoptotic cells; right upper square shows late apoptotic cells, and left upper square presents necrotic cells. 